\title{
Ukraine Data on Prognostic Factors and Treatment Outcomes in Patients with Peripheral T-Cell Lymphomas
}

\section{Ukrajinské údaje o prognostických faktorech a výsledcích léčby u pacientů s periferními T lymfomy}

\author{
Skrypets T. ${ }^{1,2}$, Novosad O. ${ }^{1}$, Pastushenko Y. ${ }^{1}$, Gorbach O. ${ }^{1}$, Kriachok I. ${ }^{1}$ \\ 'Oncohematology Department, National Cancer Institute, Kiev, Ukraine \\ ${ }^{2}$ Clinical and Experimental Medicine PhD Program, Università di Modena e Reggio Emilia, Italy
}

\begin{abstract}
Summary
Background: Peripheral T-cell lymphomas (PTCLs) is a diverse group of lymphomas (10-15\% of all non-Hodgkin's lymphomas) with aggressive behavior. Despite the standard of $1^{\text {st }}$ line anthracycline-containing regimens, clinical outcomes are poor compared to B-cell lymphomas. In addition, there are still debates about specific prognostic factors (PF) in PTCLs. Aims: Primary endpoints - event-free survival (EFS) and overall survival (OS). To evaluate the prognostic significance of five PTCLs scores (International Prognostic Index - IPI, International Peripheral T-cell lymphoma Project Score - IPTCL, Prognostic Index for T-cell lymphoma - PIT, modified Prognostic Index for T-cell lymphoma - mPIT and T-cell score). Patients and methods: From 67 enrolled patients, only 50 were included: PTCL not otherwise specified $(22,44 \%)$, anaplastic large cell lymphoma ALK+ (anaplastic lymphoma kinase-positive) $(10,20 \%)$ and ALK- (anaplastic lymphoma kinase-negative) $(18,36 \%)$. Patients received CHOP-like regimens (CHOP, CHOEP, EPOCH). Results: The overall rate response was observed in $66 \%$ of cases (complete response $78 \%$ ). There were $48 \%$ of relapses after the $1^{\text {st }}$ line therapy during follow-up (median 11 months; range 1-85 months). Median age 57 (range 22-80) with male predominance $62 \%$. In total, $40 \%$ of patients were $>60$ years old, $48 \%$ had stage III-IV. Majority of patients were assessed by five prognostic scores. IPI (45 patients): the 3-year EFS and OS were higher for $\mathrm{IPI} \leq 1$ vs. IPI $>2$ ( 80 vs. $18 \%$ and 87 vs. $27 \%$, respectively; $p=0.0002$ ). Receiver operating characteristic analysis confirmed poor clinical outcome to patients with PF $>1(\mathrm{Se}=88 \%$; Sp $=68 \%$; $A U C=0.7 ; p=0.0081)$. IPTCLP (41 patients): the presence of PF $=1-2$ showed EFS and OS reduction. A 3-year EFS rate for $1-2 \mathrm{PF}$ was 25 vs. $70 \%$ for $P F=0(p=0.003)$. Thus, 3-year OS in patients with $P F=0$ vs. $P F=1-2$ was 100 vs. $20 \%(p=0.0001)$. PIT ( 42 patients): better 3 -year EFS and $O S$ in patients with $P F=0$ vs. $P F=1-3$ ( 88 vs. $28 \%$ and 100 vs. $34 \%$, respectively, $p=0.001)$. Patients with $P F=1-3$ have a higher rate of relapses vs. $P F=0$ ( $p=0.0005$ by Cox-test). mPIT (21 patients): no significant difference between PF and clinical outcomes. T-cell score (18 patients): higher survival rates with $P F \leq 2$. More than 2 PF have an impact on EFS $(p=0.005)$. The 3 -years OS in patients with PF $\leq 2$ was 77 vs. $25 \%$ in cases with $P F \geq 3(p=0.001)$. Conclusion: IPI, PIT, IPTCLP are still very useful in defining risk stratification. As to mPIT and T-cell score, more patients to evaluate their prognostication possibility are needed.
\end{abstract}

Key words

peripheral T-cell lymphomas - prognostic factors - peripheral T-cell lymphomas not otherwise specified - anaplastic lymphoma kinase-positive - anaplastic lymphoma kinase-negative
The authors declare they have no potential conflicts of interest concerning drugs, products, or services used in the study.

Autor̆i deklarují, že $v$ souvislosti s predmětem studie nemaji žádné komerční zájmy.

The Editorial Board declares that the manuscript met the ICMJE recommendation for biomedical papers.

Redakční rada potvrzuje, že rukopis práce splnil ICMJE kritéria pro publikace zasílané do biomedicínských časopisů

\section{$\equiv$}

Tetiana Skrypets, MD Oncohematology Department National Cancer Institute 33/43 Lomonosova street 03022 Kiev, Ukraine e-mail: tetianaskrypets@gmail.com

Submitted/Obdrženo: 18. 7. 2019 Accepted/Prijijato: 13. 10. 2019

doi: 10.14735/amko2019436 


\begin{abstract}
Souhrn
Východiska: Periferní T lymfomy (peripheral T-cell lymphomas - PTCL) jsou různorodou skupinou lymfomů (10-15 \% všech non-Hodgkinových lymfomů) s agresivním chováním. I přes standardní režimy obsahující antracykliny v 1. linii jsou klinické výsledky ve srovnání s lymfomy B buněk špatné. Rovněž se stále vedou diskuze o specifických prognostických faktorech (PF) v PTCL. Cíle: Primární cíle - přežití bez príhody (event-free survival EFS) a celkové přežití (overall survival - OS). Vyhodnotit prognostický význam pěti skóre PTCL (Mezinárodní prognostický index - IPI, Mezinárodní projektové skóre periferního T lymfomu - IPTCL, Prognostický index pro T lymfom - PIT, upravený prognostický index pro T lymfom - mPIT a T-skóre buněk). Pacienti a metody: Z 67 registrovaných pacientů bylo zahrnuto pouze 50: PTCL bliže nespecifikované (22, 44 \%), anaplastický velkobuněčný lymfom ALK+ (pozitivní anaplastická lymfomová kináza) (10, 20 \%) a ALK- (negativní anaplastická lymfomová kináza) (18, 36 \%). Pacienti dostávali režimy CHOP (CHOP, CHOEP, EPOCH). Výsledky: Celková četnost odpovědí byla pozorována v 66 \% př́padů (úplná odpověd’ 78 \%). Během následné léčby došlo ve 48 \% k relapsům (medián 11 měsíců; rozmezí 1-85 měsíců). Průměrný věk 57 let (rozmezí 22-80), s převahou mužů 62 \%. Celkem 40 \% pacientů bylo starších 60 let, 48 \% mělo stadium III-IV. Většina pacientů byla hodnocena pěti prognostickými skóre. IPI (45 pacientů): 3 leté EFS a OS byly vyšší s IPI $\leq 1$ vs. IPI > 2 ( 80 vs. $18 \%$ a 87 vs. $27 \% ; p=0,0002$ ). Analýza ROC (receiver operating characteristic) potvrdila špatný klinický výsledek u pacientů S PF > 1 (Se= $88 \% ; \mathrm{Sp}=68 \% ; \mathrm{AUC}=0,7 ; \mathrm{p}=0,0081)$. IPTCLP (41 pacientů): př́tomnost PF = 1-2 vykazovala snížení EFS a OS. Tríleté EFS pro $1-2 \mathrm{PF}$ bylo 25 vs. $70 \%$ pro $P F=0(p=0,003)$. Tudíz 3leté OS u pacientů s PF $=0$ vs. $P F=1-2$ bylo 100 vs. $20 \%(p=0,0001)$. PIT (42 pacientů): lepší 3leté EFS a OS u pacientů S $P F=0$ vs. $P F=1-3$ ( 88 vs. $28 \%$ a 100 vs. $34 \% ; ~ p=0,001)$. Pacienti s $P F=1-3$ mají vyšší míru relapsů než PF $=0$ ( $p=0,0005$ Coxovým testem). mPIT (21 pacientů): žádný významný rozdíl mezi PF a klinickými výsledky. Skóre T buněk (18 pacientů): vyšší míra přežití $s P F \leq 2$. Více než $2 \mathrm{PF}$ mají dopad na EFS $(p=0,005)$. Tř́leté $O S$ u pacientů s $P F \leq 2$ bylo 77 vs. $25 \%$ v prípadech $s P F \geq 3$ ( $p=0,001)$. Závěr: IPI, PIT, IPTCLP jsou stále velmi užitečné při definování stratifikace rizika. Pokud jde o skóre mPIT a T buněk, je třeba více pacientů, aby bylo možné vyhodnotit jejich prognostické možnosti.
\end{abstract}

\title{
Klíčová slova
}

periferní T lymfomy - prognostické faktory - periferní T lymfomy bliže nespecifikované - pozitivní anaplastická lymfomová kináza - negativní anaplastická lymfomová kináza

\section{Introduction}

The classification of non-Hodgkin's lymphoma (NHL) has evolved steadily during the last several decades. In the 1950s, Rappaport et al. recognized the importance of the growth pattern in NHL and used pattern, cell size and shape as the basis of a classification [1]. In the 1970s, recognition that NHL cells were derived from $\mathrm{T}$ - or B-cells led to the immunologically based classification of Lukes and Collins and the Kiel classification of Lennert $[2,3]$. The Working Formulation was proposed in 1982 in an attempt to unify the various classifications. In 1994, a group of pathologists (the International Lymphoma Study Group) proposed a classification of lymphoid neoplasms [4].

Due to the 2016 World Health Organization (WHO) classification, there are more than 20 types of mature $\mathrm{T}$ - and natural killer neoplasms (Tab. 1), with its heterogeneous nature and genetic characteristics. Between all lymphoid neoplasms, peripheral T-cell lymphomas (PTCL) counts only near $10-15 \%$ by different data $[5,6]$. The incidence of PTCL depends on geographical region. It is well-known that incidence of PTCLs is more frequent in Asia, Central and
South America compared to Europe. However, in Europe and North America, nodal disease is more common than in Asia and South America, where extranodal cases prevalence is observed $[7,8]$. Usually, the disease more often occurs in male, but women are not an exception. Predominantly, PTCL are diagnosed in middle and elderly age groups [9].

Nowadays, there are four more prevalent types of PTCL: anaplastic large cell lymphoma ( $A L C L)$, what could be ALCL anaplastic lymphoma kinase-positive (ALK+) and anaplastic lymphoma kinase-negative (ALK-), angioimmunoblastic lymphoma and peripheral T-cell lymphoma not otherwise specified (PTCL-NOS) [6]. PTCLs are an extremely heterogeneous group with different "mixed luggage" clinical and pathological features, but still lack of clearer information to define it in one entity.

Unfortunately, compared to B-cell lymphomas, outcome prognostic rates in PTCL are lower, in spite of numerous treatment options and ongoing clinical trials. Prognostic scores for patients with PTCL are still under investigation. There are two large retrospective studies organized by the International T-Cell Project and the British Columbia
Cancer Agency, but prospective data are still missing. Despite this, risk factors are being studied and described in countless studies, but there are still a lot of debates about their clinical implementation.

\section{Patients and methods \\ Study population}

During the last 9 years, from August 2009 to April 2018, we analyzed PTCL patients at the Department of Oncohematology of the National Cancer Institute.

Approximately $80 \%$ of all cases have been evaluated in the pathology laboratory of the National Cancer Institute in Kiev, Ukraine. Other cases have been received from pathological laboratories in different Ukrainian centers. All pathology reports were reviewed according to the last edition of the WHO classification of lymphoid neoplasms (2016). Only PTCL-NOS, ALCL ALK+ and ALCL ALK- cases were included in the analysis because of their prevalence between other subtypes. Treatment response was mostly assessed by computed tomography scan or positron emission tomography/computed tomography. All data collection has been done by gathering information manually and via electronic local database. 
Prognostic scores in PTCL

One of the main ideas of this study was to analyze present prognostic scores: International Prognostic Index (IPI), Prognostic Index for T-cell lymphoma (PIT), International Peripheral T-cell lymphoma Project Score (IPTCLP), modified Prognostic Index for T-cell lymphoma - MPIT and the new one - T-cell score [10-14].

The IPI was calculated as a primary scale to assess outcomes in patients with NHL's. Factors for poor prognosis were age $>60$ years, stage III/IV disease, elevated lactate dehydrogenase (LDH) level, Eastern Cooperative Oncology Group (ECOG) performance status 2, more than one extranodal site of disease. Number of risk factors identified four groups: 0-1 low; 2 low intermediate; 3 high intermediate and 4-5 high.

The PIT score was evaluated by four prognostic factors (PF): age (<60 vs. > 60), performance status (ECOG 1 vs. $>$ 2), LDH level (low vs. high) and bone marrow involvement (negative vs. positive). Due to $P F$, patients were divided into four groups: low-risk, low-intermediate-risk, high-intermediate-risk or high-risk groups.

The IPTCLP prognostic model includes three variables: age ( $<60$ vs. $>60$ ), performance status (ECOG 1 vs. $>2$ ) and platelet cell count $\left(<150 \times 10^{9} / \mathrm{L}\right.$ vs. $\left.>150 \times 10^{9} / \mathrm{L}\right)$. As in previous prognostic models, patients were classified into low-risk, low-intermediate-risk, high-intermediate-risk or high-risk groups.

The MPIT score has the same PF as PIT score with addition of $\mathrm{Ki}-67$ immunostaining ( $<75 \%$ vs. $>75 \%)$, age ( $<60$ vs. $>60)$, performance status (ECOG 1 vs. $>2$ ), LDH level (low vs. high) and bone marrow involvement (negative vs. positive). After calculating all PF, patients were classified into low-risk, intermediate-risk or high-risk groups.

Three prognostic groups were identified by T-cell score: low-risk, intermediate risk, and high-risk groups, based on the inclusion of ECOG ( $<1$ vs. $>1$ ) Ann Arbor stage (I-II vs. III-IV) Albu$\min (>3.5$ vs. $<3.5 \mathrm{~g} / \mathrm{dL}$ ) and absolute neutrophil count (ANC) $\left(<6.5 \times 10^{9} / \mathrm{L}\right.$ vs. $\left.>6.5 \times 10^{9} / \mathrm{L}\right)$ evaluation.

Tab. 1. 2016 World Health Organization classification of mature T and NK neoplasms.

\section{mature T and NK neoplasms}

T-cell prolymphocytic leukemia

T-cell large granular lymphocytic leukemia

chronic lymphoproliferative disorder of NK cells

\section{Aggressive NK-cell leukemia}

systemic EBV+ T-cell lymphoma of childhood

Hydroa vacciniforme-like lymphoproliferative disorder*

adult T-cell leukemia/lymphoma

\section{Extranodal NK-/T-cell lymphoma, nasal type}

enteropathy-associated T-cell lymphoma

Monomorphic epitheliotropic intestinal T-cell lymphoma*

indolent T-cell lymphoproliferative disorder of the gastrointestinal tract*

\section{Hepatosplenic T-cell lymphoma}

subcutaneous panniculitis-like T-cell lymphoma

\section{Mycosis fungoides}

sezary syndrome

Primary cutaneous $\mathrm{CD}^{3} 0^{+} \mathrm{T}$-cell lymphoproliferative disorder

lymphomatoid papulosi

Primary cutaneous anaplastic large cell lymphoma

primary cutaneous gamma/delta T-cell lymphoma

Primary cutaneous $\mathrm{CD}^{+}$aggressive epidermotropic cytotoxic T-cell lymphoma primary cutaneous acral CD8 ${ }^{+}$T-cell lymphoma*

Primary cutaneous CD4+ small/medium T-cell lymphoproliferative disorder peripheral T-cell lymphoma, NOS

\section{Angioimmunoblastic T-cell lymphoma}

follicular T-cell lymphoma*

\section{Nodal peripheral T-cell lymphoma with TFH phenotype*}

anaplastic large-cell lymphoma ALK+

\section{Anaplastic large-cell lymphoma ALK-*}

breast implant-associated anaplastic large-cell lymphoma*

* changes from the 2008 classification

T neoplasms - neoplasms from T cells, NK - natural killer, EBV - Epstein-Barr virus, NOS - not otherwise specified, TFH - T follicular helper, ALK - anaplastic lymphoma kinase

\section{Statistical analysis}

Event-free survival (EFS) was defined as the time from diagnosis to either disease progression or relapse, or to death (from any cause). Data were censored if the patients were alive and free of progression/relapse at last follow-up. Overall survival (OS) was defined as the time from diagnosis to death from any cause. Data were censored if the patients were alive at the last follow-up. Survival curves were calculated by the method of Kaplan and Meier, statistical significance of parameters differences was determined using Log-rank test and Chi-square test. To investigate the contri- 
Tab. 2. Patients characteristics with PTCL (PTCL-NOS, ALCL+, ALCL-).

\begin{tabular}{|c|c|c|c|}
\hline & $\mathbf{N}$ total & $\mathbf{N}$ & $\%$ \\
\hline Median age (years) & 50 & $57(22-80)$ & \\
\hline Age $\geq 60$ years & 50 & 20 & 40 \\
\hline Gender (male) & 50 & 31 & 62 \\
\hline $\begin{array}{l}\text { Histology type, n (\%) } \\
\text { PTCL-NOS } \\
\text { ALCL+ } \\
\text { ALCL- }\end{array}$ & 50 & $\begin{array}{l}22 \\
10 \\
18\end{array}$ & $\begin{array}{l}44 \\
20 \\
36\end{array}$ \\
\hline ECOG >1 & 50 & 15 & 30 \\
\hline Ann Arbor stage III-IV & 50 & 24 & 48 \\
\hline B symptoms & 50 & 26 & 52 \\
\hline Bulky disease & 50 & 3 & 6 \\
\hline Extranodal involvement sites $\geq 2$ & 50 & 11 & 22 \\
\hline Bone marrow involvement & 50 & 7 & 14 \\
\hline Low albumin level $<3.5 \mathrm{~g} / \mathrm{L}$ & 28 & 5 & 18 \\
\hline High Ki-67 level > 75\% & 27 & 12 & 44 \\
\hline Platelets $<150 \times 10^{9} / \mathrm{L}$ & 50 & 9 & 18 \\
\hline ANC $>6.5 \times 10^{9}$ cells $/ L$ & 50 & 12 & 24 \\
\hline \multicolumn{4}{|l|}{$1^{\text {st }}$-line treatment } \\
\hline CHOP + CHOP - like & 50 & 25 & 50 \\
\hline CHOEP & 50 & 16 & 32 \\
\hline Da-EPOCH & 50 & 8 & 16 \\
\hline Only radiation therapy & 50 & 1 & 2 \\
\hline
\end{tabular}

PTCL - peripheral T-cell lymphomas, PTCL-NOS - peripheral T-cell lymphomas not otherwise specifies, $\mathrm{ALCL}+-$ anaplastic large cell lymphoma positive, $\mathrm{ALCL}-$ anaplastic large cell lymphoma negative, ECOG - Eastern Cooperative Oncology Group, ANC absolute neutrophil count, $\mathrm{CHOP}$ - cyclophosphamide/doxorubicin/vincristine/prednisone, CHOEP - cyclophosphamide/doxorubicin/etoposide/vincristine/prednisone, Da-EPOCH - etoposide/prednisone/vincristine/cyclophosphamide/doxorubicin

Tab. 3. Number of patients (from all included in the study - 50) assessed by prognostic scores.

\begin{tabular}{l|c|c|}
\hline & N total & $\%$ \\
\hline International Prognostic Index & 45 & 90 \\
\hline Prognostic Index for T-cell lymphoma & 42 & 84 \\
\hline International Peripheral T-cell lymphoma Project Score & 41 & 82 \\
\hline modified Prognostic Index for T-cell lymphoma & 21 & 42 \\
\hline T-cell score & 18 & 36 \\
\hline
\end{tabular}

bution of individual prognostic factors, the Cox proportional hazards regression model was performed. Hazard ratio (HR) with 95\% confidence intervals (Cl) was calculated for factors identified by this regression model. The difference was considered statistically significant at $p<0.05$. The data was statistically pro- cessed using Statistica 10 and MedCalc 12.6.1.0 software.

\section{Patients characteristics}

We registered 67 PTCL patients based on the WHO classification, but only 50 patients were included with histological subtypes of PTCL-NOS (22 cases, 44\%), ALCL ALK+ (10 cases, $20 \%)$ and ALCL ALK- (18 cases, 36\%). In total, 13 patients with ALCL diagnosis but without ALK status were excluded and 2 patients with angioimmunoblastic T-cell lymphomas (AITL) due to loss of follow-up. Staging and response assessment have been done by standard protocols and generally accepted criteria. Median age at diagnosis was $57(22-80)$ years with male predominance in $62 \%$ of cases. Patient characteristics at the time of diagnosis are summarized in Tab. 2.

For prognostic score assessment, the majority of patients were evaluated with IPI, PIT, IPTCLP, mPIT and T-cell score (Tab. 3). All patients received CHOP (cyclophosphamide, doxorubicin, vincristine, and prednisone) or CHOP-like regimens with or without radiation therapy.

\section{Results}

The overall rate response was observed in $66 \%$ patients of our cohort group. The survival rates by T-NHL subtype are shown in Fig. 1, 2. Early relapse or refractory disease were registered in 21 (42\%) patients, late relapse $-3(6 \%)$ after the $1^{\text {st }}$ line therapy during the follow-up period (median 11 months; range 1-85 months).

We revealed that advanced stages (III-IV), performance status (ECOG $>1$ ) and high serum level of LDH (> $620 \mathrm{U} / \mathrm{I}$ ) are unfavorable PF in patients with PTCL and can predict clinical outcomes (Fig. 3A-C).

Three-year-EFS was higher in patients with stage I-II (by Cox, $p=0.003$ ), ECOG 0 ( 50 vs. $10 \%$, log rank test, $p=0.0001$ ) and low serum level of LDH (80 vs. $25 \%$, log rank test; $p=0.0017$ ).

The same data were found in our cohort for OS. The level of 3-year-OS was lower in patients with stage III-IV (30 vs. $66 \%$, log rank test; $p=0.003$ ), ECOG < 1 (15 vs. $65 \%$, log rank test; $p=0.0001)$ and high 


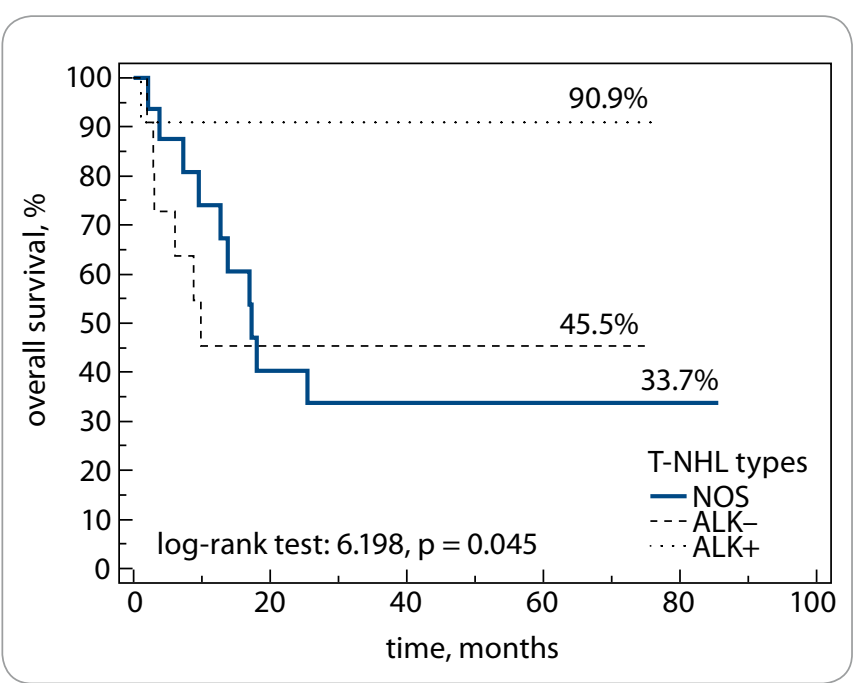

Fig. 1. Overall survival by T-NHL subtype.

T-NHL - T-cell non-Hodgkin's lymphoma, NOS - not otherwise specified, ALK - anaplastic lymphoma kinase

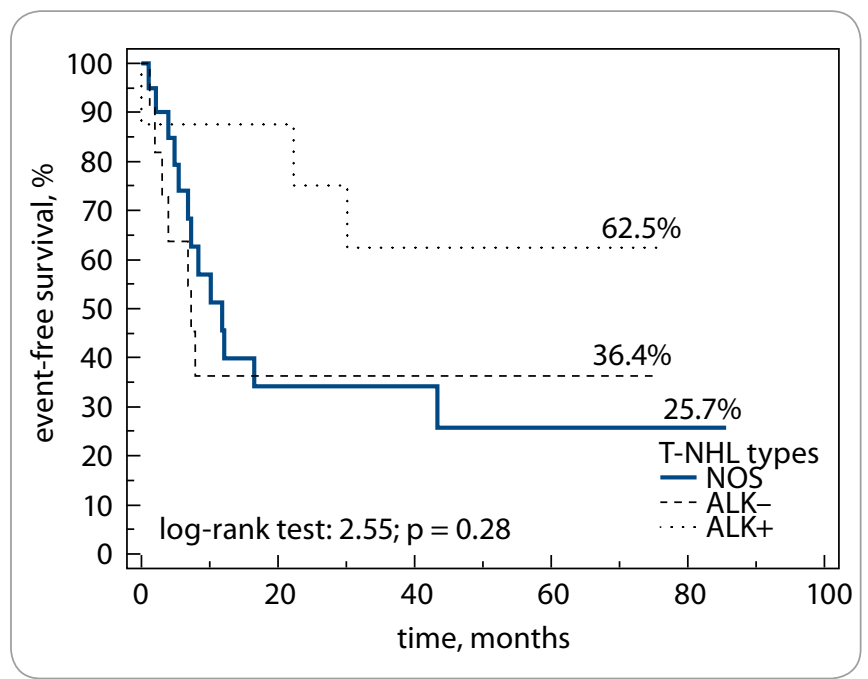

Fig. 2. Event-free survival by T-NHL subtype.

T-NHL - T-cell non-Hodgkin's lymphoma, NOS - not otherwise specified, ALK - anaplastic lymphoma kinase
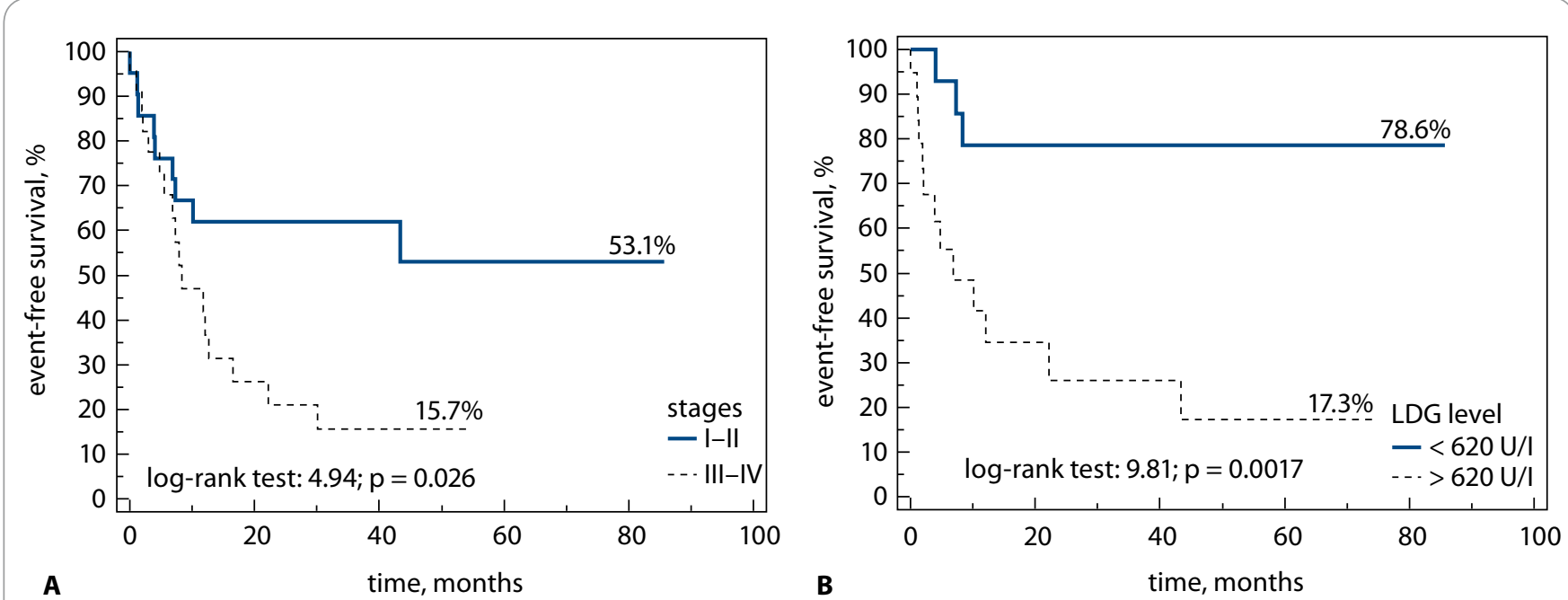

A

time, months

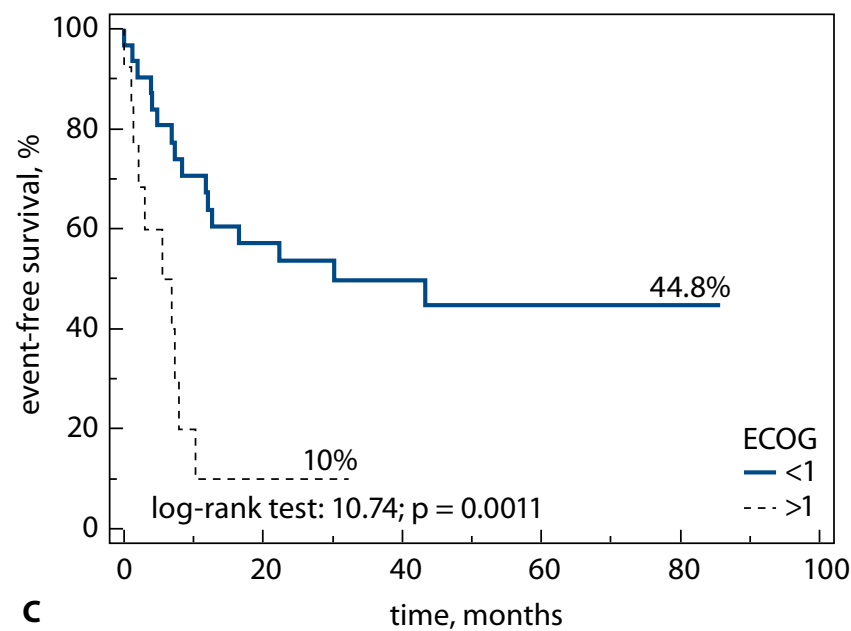

Fig. 3A-C. Clinical outcomes.

LDG - lactate dehydrogenase, ECOG - Eastern Cooperative Oncology Group 

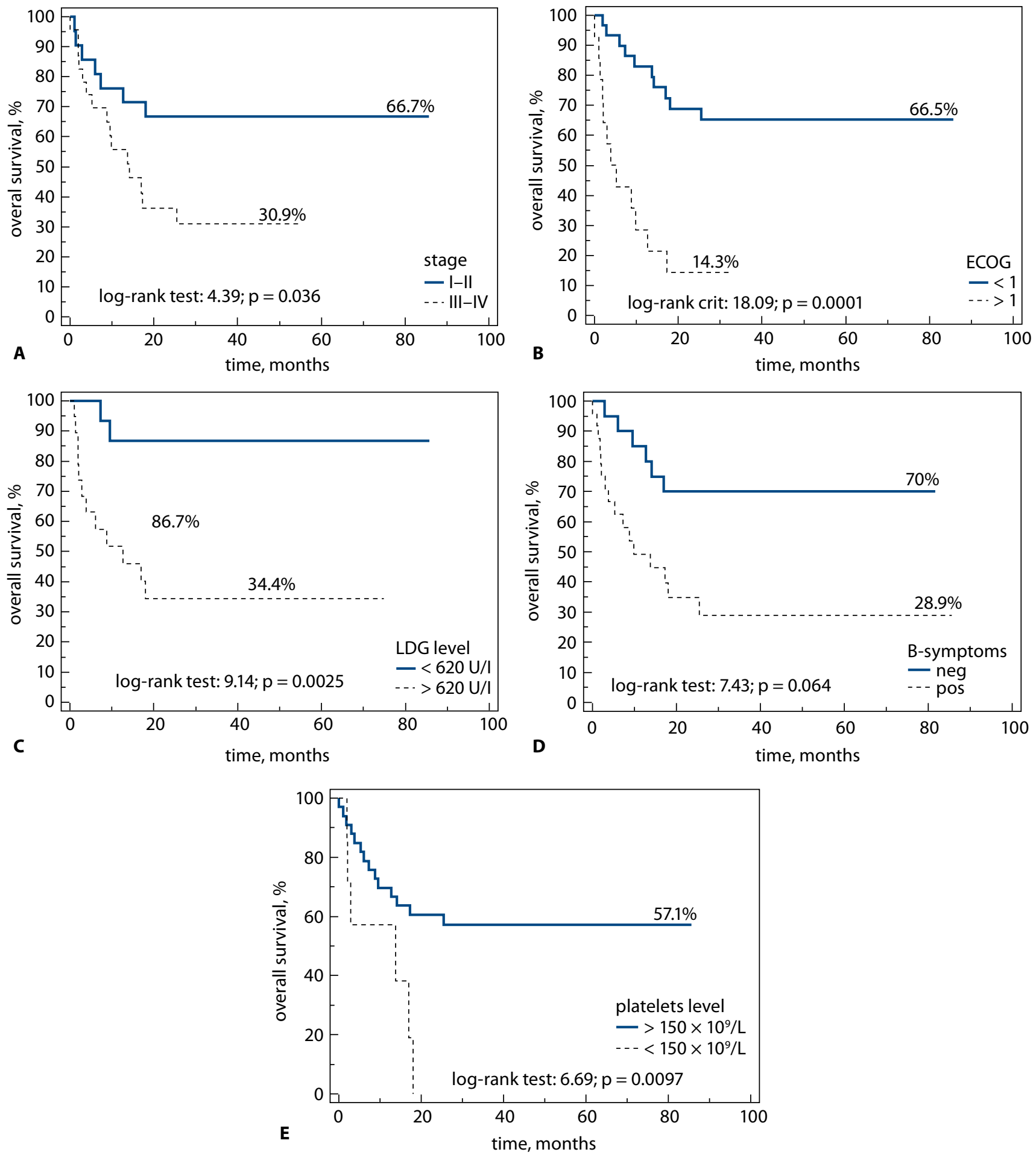

Fig. 4A-E. Poor clinical outcomes.

ECOG - Eastern Cooperative Oncology Group, LDG - lactate dehydrogenase, B-symptoms - fever, night sweats, weight loss

serum level of LDH (35 vs. 85\%, log rank test; $p=0.0009)$. Receiver operating characteristic (ROC) analysis confirmed all data for stage III-IV (sensitiv- ity $(\mathrm{Se})=68 \%$; specificity $(\mathrm{Sp})=63 \%$; area under the curve $(A \cup C)=0.65$ $\mathrm{p}=0.02), \mathrm{ECOG}>1$ (Se $=55 \% ; \mathrm{Sp}=90 \%$; $A U C=0.72 ; p=0.0003)$ and high LDH
$(\mathrm{Se}=85 \% ; \mathrm{Sp}=65 \% ; \mathrm{AUC}=0.75 ;$ $\mathrm{p}=0.0005)$.

In addition, the presence of B-symptoms was shown to play an important 
Tab. 4. Patients assessed with International Prognostic Index.

\begin{tabular}{|c|c|c|c|c|c|c|}
\hline & \multicolumn{6}{|c|}{ International Prognostic Index } \\
\hline & \multicolumn{2}{|c|}{ PTCL-NOS } & \multicolumn{2}{|c|}{ ALCL+ } & \multicolumn{2}{|c|}{ ALCL- } \\
\hline & $\mathbf{N}$ & $\%$ & $\mathbf{N}$ & $\%$ & $\mathbf{N}$ & $\%$ \\
\hline low risk (0-2) & 10 & 22 & 7 & 16 & 11 & 24 \\
\hline high risk (3-5) & 9 & 20 & 3 & 7 & 5 & 11 \\
\hline
\end{tabular}

role in prognosis of 3-year-OS (70 vs. $28 \%$, log rank; $p=0.006)$ as well as low platelet $(\mathrm{PLT})$ count $\left(\mathrm{PLT}<150 \times 10^{9} / \mathrm{L}\right)$ showed poor clinical outcomes (Fig. 4A-E). Thus, 1 -year OS was better in patients with normal vs. low level of PLT (58 vs. $20 \%$, respectively, log rank test; $p=0.009$ ).

Patients who achieved any type of response had higher 3-year EFS and OS compared to patients without response (73 vs. $15 \%$ and 80 vs. $15 \%$, respectively, log rank; $p<0.0001)$. No difference between $1^{\text {st }}$ line chemotherapy with or without adding etoposide and presence of radiation therapy to EFS and OS.

\section{Outcomes in different prognostic groups}

All patients in study group were assessed by prognostic scores. The number of patients in the investigation scores-groups were approximately equal.

\section{IPI (45 patients)}

The 3-year EFS and OS were significantly higher in patients with IPI $\leq 1$ vs. IPI > 2 ( 80 vs. $18 \%$ and 87 vs. $27 \%$, respectively; $p=0.0002$ ). ROC analysis confirmed that patients with PF $>1$ are associated with poor clinical outcome $(\mathrm{Se}=88 \% ; \mathrm{Sp}=68 \%$; $\mathrm{AUC}=0.7$; $\mathrm{p}=0.0081)($ Tab. 4).

\section{IPTCLP (41 patients)}

The presence of $\mathrm{PF}=1-2$ were associated with the reduced EFS and OS in T-NHL patients. A 3-year EFS rate for $\mathrm{PF}=1-2$ was $25 \%$ compared with $70 \%$ for $\mathrm{PF}=0$ of T-NHL patients (log rank test; $p=0.003$ ) (Tab. 5).

At the same time, OS was calculated. Using Kaplan-Meier, 3-year OS in pa- tients in this group with $\mathrm{PF}=0$ was better vs. $P F=1-2$ (100 vs. $20 \%$, respectively, log rank test; $p=0.0001)$. The prognostic significance of $P F=0$ in clinical outcome of T-NHL (OS) was also confirmed with multivariate analysis ( $\mathrm{HR}=1.2 ; 95 \%$ Cl 1.8-6.5; $p=0.0001$ ).

\section{PIT (42 patients)}

Kaplan-Mayer assessment showed better results of 3-year EFS and OS in patients with $P F=0$ vs. $P F=1-3$ (88 vs. $28 \%$ and 100 vs. $34 \%$, respectively, log rank test; $p=0.001$ ). Patients with $\mathrm{PF}=1-3$ had a higher rate of relapse, comparing to absence of PF ( $p=0.0005$ by Cox-test) (Tab. 6).

\section{mPIT (21 patients)}

There was no significant difference between PF and clinical outcomes in this group (Tab. 7).

\section{T-cell score (18 patients)}

We revealed that survival rates were better if $\mathrm{PF} \leq 2$. Thus, more than $2 \mathrm{PF}$ influenced EFS ( $p=0.005$ by Cox). Notably, 3 -year OS in patients with PF $\leq 2$ was 77 vs. $25 \%$ in cases with $P F \geq 3$ (log rank test; $p=0.001$ ). However, no significant difference between PF and PFS was found (Tab. 8).

No significant difference was found between bone marrow involvement, age, gender, Ki-67, albumin, ANC, and EFS or OS rate.

\section{Discussion}

This study was based on the Ukrainian population over a 10-year period. It is the largest Ukrainian population-based data reported about PTCL, despite the fact that it is a single-center experience.
National Cancer Institute provides therapy to people from all over Ukraine. Although, there are no previous available population based reports from east European countries. Moreover, this is the first study where patients were analyzed using all five prognostic scores: IPI, PIT, IPTCLP, mPIT and T-cell score.

It is known that PTCL has a large epidemiological variation in different geographical regions. Using data of The International T-Cell Project, the most frequent types of PTCL are PTCL-NOS, AITL, ALCL (ALK-), ALCL (ALK+) and NK/T-cell lymphoma [8]. In Europe, PTCL-NOS and AITL are more frequent than the other three, confirmed by several studies $[8,15]$. However, in our analysis, PTCL-NOS was observed in a majority of patients, while only two cases with AITL were presented and excluded from analysis, because of unclear data records. Our study has two limitations - absence of Ukrainian data registry and central pathology review. We can also mention a small number of patients as a limitation, but it is a single-center study.

The median age of patients in our cohort is lower compared to previously published large studies $[10,15,16]$. It could be explained by a shorter lifetime in the Ukrainian population compared to the European one. Nevertheless, OS rates are comparable with international data presented in the T-Cell Project $[10,15]$.

There are still debates about risk stratification of PTCL, since the standard $1^{\text {st }}$ line of treatment results in poor outcome of major PTCL types. In our study, we did not observe any crucial difference between prognostic scores in sur- 
Tab. 5. Patients assessed with International Peripheral T-cell lymphoma Project Score.

\begin{tabular}{|c|c|c|c|c|c|c|}
\hline & \multicolumn{6}{|c|}{ International Peripheral T-cell lymphoma Project Score } \\
\hline & \multicolumn{2}{|c|}{ PTCL-NOS } & \multicolumn{2}{|c|}{ ALCL+ } & \multicolumn{2}{|c|}{ ALCL- } \\
\hline & $\mathbf{N}$ & $\%$ & $\mathbf{N}$ & $\%$ & $\mathbf{N}$ & $\%$ \\
\hline low risk (0-1) & 12 & 63 & 8 & 80 & 9 & 75 \\
\hline high risk (2-3) & 7 & 37 & 2 & 20 & 3 & 25 \\
\hline
\end{tabular}

PTCL-NOS - peripheral T-cell lymphomas not otherwise specifies, ALCL+ - anaplastic large cell lymphoma positive, ALCL- anaplastic large cell lymphoma negative

Tab. 6. Patients assessed with Prognostic Index for T-cell lymphoma.

\begin{tabular}{|c|c|c|c|c|c|c|}
\hline & \multicolumn{6}{|c|}{ Prognostic Index for T-cell lymphoma } \\
\hline & \multicolumn{2}{|c|}{ PTCL-NOS } & \multicolumn{2}{|c|}{ ALCL+ } & \multicolumn{2}{|c|}{ ALCL- } \\
\hline & $\mathbf{N}$ & $\%$ & $\mathbf{N}$ & $\%$ & $\mathbf{N}$ & $\%$ \\
\hline low risk (0-2) & 15 & 83 & 8 & 80 & 12 & 86 \\
\hline high risk (3-5) & 3 & 17 & 2 & 20 & 2 & 14 \\
\hline
\end{tabular}

PTCL-NOS - peripheral T-cell lymphomas not otherwise specifies, ALCL+ - anaplastic large cell lymphoma positive, ALCL- anaplastic large cell lymphoma negative

Tab. 7. Patients assessed with modified Prognostic Index for T-cell lymphoma.

\begin{tabular}{|c|c|c|c|c|c|c|}
\hline & \multicolumn{6}{|c|}{ modified Prognostic Index for T-cell lymphoma } \\
\hline & \multicolumn{2}{|c|}{ PTCL-NOS } & \multicolumn{2}{|c|}{ ALCL+ } & \multicolumn{2}{|c|}{ ALCL- } \\
\hline & $\mathbf{N}$ & $\%$ & $\mathbf{N}$ & $\%$ & $\mathbf{N}$ & $\%$ \\
\hline low risk (0-2) & 7 & 78 & 3 & 50 & 3 & 50 \\
\hline high risk (3-5) & 2 & 22 & 3 & 50 & 3 & 50 \\
\hline
\end{tabular}

vival rates; however, we did not receive any significant data from $\mathrm{MPIT}$, and EFS rate using T-cell score. Possibly, the number of patients assessed by these two scores was lower, than in group of PIT, IPI and IPTCLP (Tab. 3). The MPIT was assessed in $42 \%$ of patients, where Ki-67 was available using immunohistochemistry reports. The same situation was observed for T-cell score, where only $36 \%$ of patients were analyzed, due to the lack of the electronic database with all laboratory counts of albumin and ANC.
As previously mentioned in results, we identified several factors from all covariates included in five prognostic scores, with a significant impact on OS (Fig. 4A-E) and EFS (Fig. 3A-C). Of course, all these scores are based on clinical characteristics; however, despite the absence of some molecular and genetic findings, they are useful in evaluating and defining risk of PTCLs. An impact of all these scores has been already confirmed in several studies, although it was proven in these ones only $[5,10]$. However, there are two most important and frequently used prognostic indices frequently used - IPI and PIT.

Moreover, we decided not to exclude patients with ALCL ALK+. A lot of previous studies showed better outcomes for this type of PTCL, but we decided to include this patient population for several reasons. The first reason - ALCL $A L K+$ is one of the most frequent type of PTCLs in the European population. Then, the definition of PTCLs in a new 2016 WHO classification includes more than 20 different types of PTCLs. Further several studies showed ALK status is not 
Tab. 8. Patients assessed with T-cell score.

\begin{tabular}{|c|c|c|c|c|c|c|}
\hline & \multicolumn{6}{|c|}{ T-cell score } \\
\hline & \multicolumn{2}{|c|}{ PTCL-NOS } & \multicolumn{2}{|c|}{ ALCL+ } & \multicolumn{2}{|c|}{ ALCL- } \\
\hline & $\mathbf{N}$ & $\%$ & $\mathbf{N}$ & $\%$ & $\mathbf{N}$ & $\%$ \\
\hline low risk (0-2) & 5 & 63 & 7 & 100 & 1 & 33 \\
\hline high risk (3-5) & 3 & 37 & 0 & 0 & 2 & 67 \\
\hline
\end{tabular}

PTCL-NOS - peripheral T-cell lymphomas not otherwise specifies, ALCL+ - anaplastic large cell lymphoma positive, ALCL- anaplastic large cell lymphoma negative

an independent prognostic factor on ALCL outcome $[15,17]$.

The treatment schedules received by patients were $>90 \%$ with anthracyclinbased regimens (CHOP; CHOEP - cyclophosphamide, doxorubicin, etoposide, vincristine, prednisone; Da-EPOCH etoposide, prednisone, vincristine, cyclophosphamide, doxorubicin). Young patients $(<65$ years old) were treated with adding etoposide in $58 \%$. However, we did not observe any influence on OS and EFS by treatment with or without adding etoposide in $1^{\text {st }}$ line treatment ( $p=0.3$ and $p=0.15$, respectively). Autologous stem cell transplantation has been done only for 2 patients in $1^{\text {st }}$ line treatment option. There are several explanations for this - lack of hematological centers where transplant could be performed, lack of financial support and mixed data about superiority of transplant in a $1^{\text {st }}$ line setting.

In conclusion, results received from this Ukrainian based-population study are similar to data from several other European based-population studies. There could be some selection bias due to limitations mentioned above. Nevertheless, the IPI, PIT, IPTCLP are still very useful in defining risk stratification. More pa- tients need to be included for evaluation according mPIT and T-cell score, in order to confirm their prognostication ability.

\section{References}

1. Hicks EB, Rappaport H, Winter WI. Follicular lymphoma: a re-evaluation of its position in the scheme of malignant lymphoma, based on a survey of 253 cases. Cancer 1956; 9(4): 792-821. doi: 10.1002/1097 0142(195607/08)9:4<792::aid-cncr2820090429>3.0.co;2-b. 2. Damber $L$, Lenner $P$, Lundgren $E$. The impact of growth pattern on survival in non-Hodgkin's lymphomas classified according to Lukes and Collins. Patho Res Pract 1982; 174(1-2): 42-52. doi: 10.1016/S0344 0338(82)80027-7.

3. Lukes RJ, Collins RD. Immunologic characterization of human malignant lymphomas. Cancer 1974; 34 (Suppl 4): 1488-1503. doi: 10.1002/1097-0142(197410) 34:8+<1488::aid-cncr2820340822>3.0.co;2-c

4. Harris $H L$, Jaffe ES, Stein $H$ et al. A revised EuropeanAmerican classification of lymphoid neoplasms: a proposal from the International Lymphoma Study Group. Blood 1994; 84(5): 1361-1392.

5. Gutiérrez-García G, García-Herrera A, Cardesa T et al. Comparison of four prognostic scores in periphera T-cell lymphoma. Ann Oncol 2011; 22(2): 397-404. doi 10.1093/annonc/mdq359.

6. Bellei M, Foss FM, Shustov AR et al. The outcome of peripheral T-cell lymphoma patients failing first-line therapy: a report from the prospective, International T-Cell Project. Haematologica 2018; 103(7): 1191-1197. doi 10.3324/haematol.2017.186577.

7. Vose JM. Peripheral T-cell non-Hodgkin's lymphoma. Hematol Oncol Clin North Am 2008; 22(5): 997-1005. doi: 10.1016/j.hoc.2008.07.010

8. Bellei M, Chiattone CS, Luminari S et al. T-cell lymphomas in South America and Europe. Rev Bras Hematol Hemoter 2012; 34(1): 42-47. doi: 10.5581/15168484.20120013.
9. Swerdlow SH, Campo E, Harris NL et al (eds). 2017. World Health Organization Classification of Tumours of Hematopoietic and Lymphoid Tissues. 4th ed. Lyon: Res Cancer Rev 2017.

10. Federico M, Bellei $M$, Marcheselli $L$ et al. Peripheral T cell lymphoma, not otherwise specified (PTCL-NOS). A new prognostic model developed by the International T cell Project Network. Br J Haematol 2018; 181(6): 760-769. doi: 10.1111/bjh.15258.

11. Gallamini A, Stelitano C, Calvi R et al. Peripheral T-cell lymphoma unspecified (PTCL-U): a new prognostic model from a retrospective multicentric clinical study. Blood 2004; 103(7): 2474-2479. doi: 10.1182/blood-2003-09-3080. 12. Vose J. International Peripheral T-cell Lymphoma (PTCL) Clinical and Pathology Review Project: poor outcome by prognostic indices and lack of efficacy with anthracyclines. Blood 2005; 106(11): 811. doi: 10.1182/blood. V106.11.811.811.

13. Shipp MA, Harrington DP, Anderson JR et al. A predictive model for aggressive non-Hodgkin's lymphoma. N Engl J Med 1993; 329(14): 987-994. doi: 10.1056/NEJM199309303291402.

14. Went P, Agostinelli C, Gallamin A et al. Marker expression in peripheral T-cell lymphoma: a proposed clinicalpathologic prognostic score. J Clin Oncol 2006; 24(16): 2472-2479. doi: 10.1200/JCO.2005.03.6327.

15. Ellin F, Landström J, Jerkeman M et al. Real-world data on prognostic factors and treatment in peripheral T-cell lymphomas: a study from the Swedish Lymphoma Registry. Blood 2014; 124(10): 1570-1577. doi: 10.1182/blood2014-04-573089.

16. Savage KJ, Chhanabhai M, Gascoyne RD et al. Characterization of peripheral T-cell lymphomas in a single North American institution by the WHO classification. Ann Oncol 2004; 15(10): 1467-1475. doi: 10.1093/annonc/mdh392.

17. Sibon D, Fournier M, Brière J et al. Long-term outcome of adults with systemic anaplastic large-cell lymphoma treated within the groupe d'Étude des Lymphomes de l'Adulte trials. J Clin Oncol 2012; 30(32): 3939-3946. doi: 10.1200/JCO.2012.42.2345. 